\title{
THE "CLASS" DISSENSION OF COLONIAL PERIOD IN SUNDANESE NOVELS: REVIEW OF IDENTITY POLITICS
}

\author{
Asep Yusup Hudayat \\ Universitas Padjadjaran \\ email: a.y.hudayat@unpad.ac.id
}

\begin{abstract}
The culture of feudalism and democracy in the Dutch East Indies agreed to oppose one another. The intersection of the two cultures is the perspective of indigenous and colonial identity which ultimately demands a struggle to demand its "class" rights. The struggle for narratives of power was inevitable. The first Sundanese novel Baruang ka nu Ngarora "Poison for the Youth" (1914) by D.K. Ardiwinata and Gogoda ka nu Ngarora "Temptations for the Youth"(1951) as an novel respons from M.A. Salmun has shown these oppositional phenomena. This study aims to trace the struggle for narration that has implications for identity politics in the Dutch East Indies colonial period. The method used in this study is descriptive analysis from the perspective of postcolonial studies. From a postcolonial perspective, literary works have become an important means for tracking colonialism practices where the narratives of dominant and defensive forces are nested. The results of the analysis show that the narrative of class disagreement in Gogoda ka nu Ngarora is used as a motive for empowering the spirit of democracy, in Baruang ka nu Ngarora, is used as a motive for the assertion of partiality towards feudal culture. Through the spirit of democracy, the struggle for identity politics was built by M.A. Salmun in Gogoda ka nu Ngarora to rejects feudal ideologies. Through a feudal spirit, identity politics was built D.K. Ardiwinata in Baruang ka nu Ngarora to establishing class identity.
\end{abstract}

Keywords: identity politics, class, native, colonial

\section{PERTENTANGAN "KELAS" PADA MASA KOLONIAL DALAM NOVEL SUNDA: TINJAUAN POLITIK IDENTITAS}

\begin{abstract}
Abstrak
Budaya feodalisme dan budaya demokratis pada masa kolonial Hindia Belanda seringkali menunjukkan pertentangan satu dengan lainnya. Persinggungan kedua budaya tersebut dipengaruhi sudut pandang tentang identitas pribumi dan kolonial yang akhirnya memicu perjuangan menuntut hak-hak "kelas"-nya. Perebutan narasi kekuasaan pun tidak dapat dihindarkan. Novel Sunda pertama Baruang ka nu Ngarora (1914) karangan D.K. Ardiwinata dan novel sambutannya Gogoda ka nu Ngarora (1951) karangan M.A. Salmun telah menunjukkan fenomena-fenomena pertentangannya tersebut. Studi ini bertujuan menjejak perebutan narasi yang berimplikasi kepada upaya politik identitas pada masa kolonial Hindia Belanda. Metode yang digunakan dalam studi ini adalah deskriptif analisis dalam perspektif studi postkolonial. Berdasarkan perspektif postkolonial, karya sastra menjadi
\end{abstract}


sarana penting untuk menjejak praktik kolonialisme tempat bersarangnya narasinarasi kekuasaan dominan dan perlawanannya. Hasil analisis menunjukkan bahwa narasi pertentangan kelas dalam Gogoda ka nu Ngarora digunakan sebagai motif pemberdayaan semangat demokrasi, dalam Baruang ka nu Ngarora digunakan sebagai motif penegas keberpihakan terhadap budaya feodal. Melalui semangat demokrasi, upaya politik identitas dibangun M.A. Salmun dalam Gogoda ka nu Ngarora untuk menolak ideologi-ideologi feodal. Melalui semangat feodal, politik identitas dibangun D.K. Ardiwinata dalam Baruang ka nu Ngarora untuk mengukuhkan identitas kelas.

Kata kunci: politik identitas, kelas, pribumi, kolonial

\section{INTRODUCTION}

Conflict of the natives with the colonials represented in literary works has been extensively investigated through cultural studies approaches, especially research which confirms the postcolonial keywords as its main signs. However, by the concept of gap \& blank from Wolfgang Iser's aesthetic response theory, the same topic has not been much researched, even though the two perspectives can be linked. A gap \& blank analysis of the aesthetic response theory can be used, one of which, as a gateway to the disclosure of "concealment" narratives. On the one hand, the "concealment" can be read as a potential that is considered aesthetic. On the other hand, the requested "concealment" can be traced to an ideological perspective according to postcolonial use. This ideological perspective can be interpreted as the potential of literary work in each process of making a narrative that is intended to build an ideology, including how to create narratives in literary works that show political traces. That traces are debated in the context of narrative processing regarding the battles between the natives and the colonials, both in the spirit of the colonial era and the spirit of the later period.
Political indications of the cultural contact, in the context of the Netherlands Indies power on the island of Java, Van Der Meer (20014: 21) mentioned that the Dutch colonial government had in many ways carried out cultural control projects. One such control strategy is to inculcate themselves in Javanese society. The Netherlands Indies Government has found a way to legitimize their authority through local customs, courtesy, and semiotics. in the $19^{\text {th }}$ century, Java did so by referring to the Javanese language feudalism and the accompanying worldview. According to him (2014: 23) during the feudalization phase, the colonial government instead relied heavily on the Javanese aristocracy and empowered their feudal positions for the purpose of more effective exploitation.

Not a few, native women in literary works on the same topic took a role in fighting the colonials. Not a few also literary works raised the struggle of women associated with class struggle and the struggle for freedom in a broad sense in social, political, and cultural upheaval it faces. In the Sundanese literary, the novel Gogoda ka nu Ngarora $(G N)$ "Temptation for Young People" by M.A. Salmun, which was published 
for the first time in 1951, is one of the literary works which is closely attached to the spirit of the struggle of women in demanding freedom during the late 19 th century colonialism through the spirit of democracy which was obtained from the beginning of modern civilization. That novel is a form of response to the novel Baruang ka nu Ngarora (BN) "Poison for Young People" by D.K. Ardiwinata which was first published in 1914.

Hudayat (2012: 137) in the results of his research on $B N$ and $G N$ concerning the resistance of women from santana "the middle class " against menak "the high class" and the colonials showed that the resistance of santana women against the class of foes in $G N$ was shown so firmly. In $G N$, the narration leads all the "classes" represented by each of the typical characters (cacah "low people", santana, and the colonials) into the snares of the world of prostitution. It is intended to form the view that all human beings without knowing "class" can fall into sin and humiliation. Women leaders from the middle class struggled to weaken the authority of the upper classes (menak and colonials) by plunging them into the world of prostitution so that both the conquerors and the colonials were labeled "despicable". Hudayat also (2012: 156) put $G N$ as an ideological balancing to $B N$. $B N$ 's novel is considered by Salmun to have carried out an unfair attitude towards the census and santana circles. As for the case of "concealment", Hudayat (2012: 148) highlights the hidden message in the work as concealment of the desires of the middle and commoners in an attempt to enter the power of conquest and the colonials by taking over their authoritative attitude. According to him, $G N$ readers were directed by Salmun to be in a position to dislike figures who instead were portrayed as $B N$ figures who were not touched by humiliation.

Using the perspective of cultural studies, Barker states that identity is often interpreted not merely as a collection of features that we have or something that we have but as a way of thinking about ourselves. Identity is attached to the signs of taste, beliefs, attitudes, and lifestyle that indicate that we have it. The ability to maintain a narrative about himself is the main goal in the exploration of identity (2005: 219). Likewise, with $G N$, the potential in it shows the problems of identity that are packaged in narrative battles between the natives (cacah, santana, menak) and between the natives and the colonials. In it are shown forms of intimidation and intense interrogation from santana to menak and the colonials. Santana explicitly reject the "class" throughout GN narration. Santana sued and attacked menak and the colonials through various gestures and actions. Their insistent attacks and attacks provide the opportunity for reading to arrive at traces of the hiding areas of the text. In this case, $G N$ clearly shows the potentials of over-determination, namely concerning the abundance of the causality of santana towards menak and the colonials which is maintained throughout the narration, both concerning the thoughts, attitudes, beliefs, and actions of the main characters representing santana. The abundance does not directly show everything but instead leaves a gap to reveal how the effectiveness of 
over-determination in $G N$ in opening perspectives on identity struggles is in line with identity politics that is being carried out in GN. Iser (1987: 48) mentions that over-determination of a text results in indetermination. The difference between literary texts and the practice of reading them is that they are verified by over-determination, while the reader's attitude is verified by analogism.

Bhaba (Loomba, 2003: 229) states that ambivalence is not only a marker of colonial subject trauma but also as a feature of the workings of colonial authorities and their resistance. The colonial presence is always ambivalent, divided between showing its authentic and authoritative self and its articulation which shows repetition and difference. These conditions can impact on the natives who are in a dilemma between accepting and rejecting the influence present in their lives.

Burgin (in Hutcheon, 2004: 4) states that all forms of cultural representationliteral, visual, aural are based on certain ideologies, so it is impossible to avoid the pattern of relations and social-political tools. Hutcheon (2004: 11) alludes to the point of meeting the documentary historical actuality with self-reflection. The meeting point in question is the study of representation that focuses on the exploration of narrative structure and structure are structured the way we see ourselves and the way we construct our self-concept, present, and past.

Identity is a discursive construction, the product of discourses, or certain ways of talking about the world. In other words, identities are created and not discovered and formed from representations (Barker, 2005: 15).
Identity is a temporary attachment to subject positions constructed for us by discursive practices. Identity is also not something universal that comes from nature, but the result of cultural production at a certain time and place. An Identity which is the creation of discourse by itself can change meaning following time, place, and usage. Identity is not eternal and permanent. Thus, identity can be said to be cultural.

The concept that we hold about ourselves can be called self-identity, while the hopes and opinions of others shape our social identity (Barker, 2005: 217). Self-identity is the self as understood by that person or the way we think about ourselves and construct self-narratives as a whole. Social identity talks about similarities and differences, about personal and social matters, about what we have in common with others, and what distinguishes us from others. Social expectations, normative rights and obligations imposed on individuals belong to the realm of social identity. An understanding of being an individual is something social and identity is formed from social and cultural resources. Cultural identity is a portrait of meaning that expresses something, related to self-nomination or the judgment/perception of others. Cultural identity is related to the vertex of cultural meaning, especially class, gender, race, ethnicity, nation, and age. Both self-identity, social identity, and cultural identity are something that is constantly being formed.

Regarding identity politics, Butler(in Brunila \& Rossi, 2018: 289) states that it is important to recognize that identity politics comes with different tastes. According to them, it is also important 
to see that by using various forms of identity politics as their tools, various social movements have succeeded in increasing the self-awareness of certain groups, and elite awareness of others who live in situations of losing their rights. For example, identity politics deal with feminists, the working class, sexual and gender minorities, disabilities, and racial or ethnic groups. The identity politics has brought all-important differences. According to Younge (2019: $11)$, the choice is whether we want to surrender to danger in panic and moral divisions or exploit its potential through solidarity, seeking equality, or even for higher interests. Regarding women's contribution to democracy, Baumeister (2009: 274) suggests that a basic framework designed to secure a degree of economic independence for women might be sufficient to ensure that women can protect their interests in formal political deliberations governed by a minimum reading of conditions for democratic participation.

In his article, Couze Venn (2010: 321) argues that works of art in various forms occupy a key place in the process of reconfiguring subjectivity and identity as a result of displacement. According to him, subjectivity is relational, realized and can be measured by referring to the material, discursive, and psychological conditions that shape it. He developed arguments that build relationships between aesthetic practices, affective economies, and the politics of change. His conclusions (2010: 345) show that the "art of anger" shows how this movement is played in an expressive life that we can learn to interpret, involving reading practices that change perspectives. This affective-aesthetic- ethical participation in solidarity with a critical work is based on politicization that challenges the ego-centric discourse of identity and normative subjectivity.

Iser (2006: 4) can assert that the same text can be "read" differently by different readers; even by one reader in different conditions has produced different readings. Readers' responses are shown through their activities in producing text again, one of them, their activities in filling the empty spaces in the text, this is where the interaction between the text and the reader becomes a field of cultural study. The Incompleteness of any disclosure or imperfection is potential gaps and blanks of the text that the reader must overcome.

Based on the reader theory in the section of Ingarden's phenomenological model, Wolfgang Iser (1987: 180-203) re-establishes indetermination in the empty form, or gap (leerstellen), in the text. Emptiness occupies a central position in the communicative function of literary works, explanations, and restrictions on the role of the reader. In its interaction with the text, implicitly, the reader is moved to move or complete various things that are empty on several levels, from the simplest relationships in the storyline to increasingly complex relationships, between themes that stand out against hidden horizons.

\section{METHOD}

This paper is intended to trace the practice of colonial identity politics contained in literary works. The main focus of the study is to trace the practice of identity politics that is potentially able to nest in narratives that leave gaps and blanks or even indetermination. 
The practice of identity in $G N$ indicates the potential for ambivalence in it. The struggle of women from santana is problematically placed from the whole set of narratives. It is not only what women are fighting for, but also how the struggle has strived in the condition of the struggle of the spirit of locality brought by the natives and the spirit of democracy brought by the colonials which influence the new indigenous awareness about the demands of equal rights and freedoms.

Based on the potential of novels and the theoretical footing described above, the method used in this study is an exploratory method that relies on keywords in postcolonial and aesthetic responses. This method was used to track the views and attitudes of the natives (cacah-menak; menak-cacah) against the colonials and vice versa. The tracking is directed at indications of the nesting identity politics that spreads in various narratives about the various contradictions within. By using the aesthetic response theory as a first step for disclosure of concealment, the postcolonial approach is used in gathering the phenomenon of the struggle for narratives, including the empowerment of the political identity of each party. The method of tracking referred to has schemed as follows.

Table 1. Instruments and Focuses Research

\begin{tabular}{|c|c|c|c|}
\hline \multirow[b]{2}{*}{$\begin{array}{c}\text { RESEARCH } \\
\text { INSTRUMENTS }\end{array}$} & \multicolumn{3}{|c|}{ FOCUSES } \\
\hline & $\begin{array}{c}C A C A H-S A N T A N A \\
\text { to } \\
M E N A K\end{array}$ & $\begin{array}{c}C A C A H-S A N T A N A \\
\text { to } \\
\text { COLONIALS }\end{array}$ & $\begin{array}{c}\text { COLONIALS } \\
\text { to } \\
\text { NATIVES }\end{array}$ \\
\hline $\begin{array}{l}\text { dissension } \\
\text { narratives }\end{array}$ & $\begin{array}{l}\text { events of conflict stem } \\
\text { from beliefs, awareness, } \\
\text { and aspirations about } \\
\text { "class" }\end{array}$ & $\begin{array}{l}\text { practice of ambivalence } \\
\text { and mimicry }\end{array}$ & $\begin{array}{l}\text { colonial subordination } \\
\text { practices to natives }\end{array}$ \\
\hline $\begin{array}{l}\text { scramble } \\
\text { narratives }\end{array}$ & $\begin{array}{l}\text { scramble motives, how } \\
\text { to fight, and the result } \\
\text { of struggle for "class" }\end{array}$ & $\begin{array}{l}\text { scramble motives, how } \\
\text { to fight, and the result } \\
\text { of struggle for "class" }\end{array}$ & $\begin{array}{l}\text { scramble motives, how } \\
\text { to fight, and the result } \\
\text { of struggle for "class" }\end{array}$ \\
\hline identity politics & $\begin{array}{l}\text { gap, blank, and over- } \\
\text { determination as a } \\
\text { strategy for the identity } \\
\text { politics forming of } \\
\text { santana to menak }\end{array}$ & $\begin{array}{l}\text { gap, blank, and over- } \\
\text { determination as a } \\
\text { strategy for the identity } \\
\text { politics forming of } \\
\text { natives to colonials }\end{array}$ & $\begin{array}{l}\text { gap, blank, and over- } \\
\text { determination as a } \\
\text { strategy for the identity } \\
\text { politics forming of } \\
\text { colonials to natives }\end{array}$ \\
\hline
\end{tabular}

\section{RESULTS AND DISCUSSION Results}

There are three focus areas of analysis in this paper: (1) dissension narratives, (2) scramble narratives, and (3) identity politics. The following is a table of data processing results: 
Tablel 2. Dessesion-Scramble-Identity Politics

\begin{tabular}{|c|c|c|c|}
\hline \multirow[b]{2}{*}{$\begin{array}{c}\text { RESEARCH } \\
\text { INSTRUMENTS }\end{array}$} & \multicolumn{3}{|c|}{ RESULT } \\
\hline & $\begin{array}{c}\text { CACAH-SANTANA } \\
\text { to } \\
\text { MENAK }\end{array}$ & $\begin{array}{c}\text { NATIVES } \\
\text { to } \\
\text { COLONIALIS } \\
\end{array}$ & $\begin{array}{c}\text { COLONIALS } \\
\text { to } \\
\text { NATIVES }\end{array}$ \\
\hline \multirow[t]{2}{*}{$\begin{array}{c}\text { dissension } \\
\text { narratives }\end{array}$} & $\begin{array}{l}B N \text { : } \\
\text { self-restraint over } \\
\text { conflicts of inequality } \\
\text { and claims for fearsome } \\
\text { misuse of santana and } \\
\text { cacah }\end{array}$ & $\begin{array}{l}B N: \\
\text { implied by the actions } \\
\text { of the menak to } \\
\text { harmonize the colonial } \\
\text { culture }\end{array}$ & $\begin{array}{l}B N: \\
\text { implied by the colonial } \\
\text { authority through the } \\
\text { order of the natural and } \\
\text { social order }\end{array}$ \\
\hline & $\begin{array}{l}G N \text { : } \\
\text { demands for class } \\
\text { equality and lawsuits } \\
\text { over the arbitrariness } \\
\text { against santana and } \\
\text { cacah }\end{array}$ & $\begin{array}{l}G N: \\
\text { The ambivalence } \\
\text { between accepting the } \\
\text { spirit of democracy } \\
\text { from indo-dutch } \\
\text { with the conditions } \\
\text { of indigenous } \\
\text { subordinated and desire } \\
\text { to imitate and oppose } \\
\text { colonial authority }\end{array}$ & $\begin{array}{l}G N \text { : } \\
\text { The colonial } \\
\text { subordination of } \\
\text { indigenous beliefs and } \\
\text { awareness of their } \\
\text { ownership rights }\end{array}$ \\
\hline \multirow[t]{2}{*}{$\begin{array}{l}\text { scramble } \\
\text { narratives }\end{array}$} & $\begin{array}{l}B N \text { : } \\
\text { the desire to be a part } \\
\text { of menak through } \\
\text { marriage and put in the } \\
\text { best position possible so } \\
\text { that it can be accepted } \\
\text { as menak }\end{array}$ & $\begin{array}{l}B \mathrm{~N} \text { : } \\
\text { the desire for colonial } \\
\text { recognition of menak by } \\
\text { increasing the authority } \\
\text { of menak over cacah \& } \\
\text { Santana }\end{array}$ & $\begin{array}{l}B N: \\
\text { not represented }\end{array}$ \\
\hline & $\begin{array}{l}G N: \\
\text { the lawsuit over } \\
\text { the arbitrariness of } \\
\text { frightening as well as } \\
\text { the desire to seize the } \\
\text { dominant narrative by } \\
\text { weakening the practice } \\
\text { of feudalism through } \\
\text { the spirit of democracy }\end{array}$ & $\begin{array}{l}G N: \\
\text { the lawsuit over colonial } \\
\text { abuse and the desire } \\
\text { to seize dominant } \\
\text { narrative by weakening } \\
\text { colonial authority } \\
\text { through the spirit of } \\
\text { democracy \& mim pitu }\end{array}$ & $\begin{array}{l}G N: \\
\text { The struggle to restore } \\
\text { colonial-dominant } \\
\text { narrative through } \\
\text { stereotypes of native } \\
\text { and colonial }\end{array}$ \\
\hline \multirow[t]{2}{*}{ identity politics } & $\begin{array}{l}B N \text { : } \\
\text { the struggle of } \\
\text { subordinated parties } \\
\text { through the formation } \\
\text { of self-image }\end{array}$ & $\begin{array}{l}B N: \\
\text { not represented }\end{array}$ & $\begin{array}{l}B N: \\
\text { not represented }\end{array}$ \\
\hline & $\begin{array}{l}G N \text { : } \\
\text { The struggle of } \\
\text { the subordinated } \\
\text { parties through spirit } \\
\text { democracy }\end{array}$ & $\begin{array}{l}G N \text { : } \\
\text { The native moral } \\
\text { empowerment through } \\
\text { the pitfalls of the } \\
\text { pitu mim in crippling } \\
\text { colonial authority }\end{array}$ & $\begin{array}{l}G N \text { : } \\
\text { the retention of } \\
\text { "white" supremacy to } \\
\text { hegemony the native } \\
\text { culture }\end{array}$ \\
\hline
\end{tabular}


The dissensions narratives were shown through contradictionsstemming from the belief in class rights and the awareness and aspirations of santana "middle class" as a subordinate group to fight for their class rights. The narrative of the conflict between the natives and the colonials is shown through santana's uncertainty in accepting and rejecting the colonial spirit and the acceptance of a democratic spirit for the achievement of the desire to defeat the authority of the conquerors. The dispute of the narratives shown by the colonials against the natives was presented through Indo-Dutch youth who remained dominant and in power over the natives.

The scramble narratives in $G N$ were carried out by santana in an attempt to take over the authority of the throne. The struggle was carried out in a direct, straightforward, and blatant manner. The results show that santana through the main female character named Nyi Rapiah has succeeded in weakening the authority of menak "aristrocatic natives". The motive of the scramble narratives is as an effort to fulfill the knowledge of democracy. The struggle of native narratives to colonials was motivated by the fulfillment of knowledge about democracy brought by the colonials. That struggle was carried out by utilizing the body of Nyi Rapiah to be accepted in an indigenous association with the Indo-Dutch. The results of the struggle over the narration showed the formation of the power of santana to oppose class differences.

The motives for the struggle for narratives carried out by the colonials were as an effort to fulfill sexual desires and to maintain the narrative of the domination and power of the colonials. The struggle for narration in it is carried out by utilizing the body of indigenous women in the graduation of the sexual desire of Indo-Dutch youth as well as a form of colonial subordination of the natives. The results of the struggle and retention of the narrative did not weaken the spirit of native women in demanding equal rights, including becoming a modern self in the spirit of democracy.

Identity politics in $G N$ is carried out through over-determination as a strategy for the formation of santana's identity politics towards enchanting. The same strategy was carried out by santana against the authority of the colonials. The politics of identity carried out by the colonials against the natives is to maintain the narrative of domination \& power of the first nation while introducing modern cultures as a civilization that must be owned by the natives.

\section{Discussion \\ Dissension and Scramble Narratives}

The Dissensions in $B N$ and $G N$ novels were presented in forms of internal and native conflict with the natives with the colonial. The dissension in the $B N$ were sourced from the desires of the santana women who wanted to move running to a aristocrats. The dissension only discussed the conflict between the santana "middle-class natives". The dissension in commitment for the sake of the santana remains subordinated by aristocrats natives. In the $G N$, conflict further not only limited to class problems, but the share of democracy that caused the santana and cacah "commoners" to demand 
freedom, equality, and allow both against the natives and the colonial.

The narration scrambles are represented through forms of intimidation and interrogation mainly by the santana against the aristocrats native and colonials. Narrative disputes at $B N$ are only limited to internal disputes relating to group desires. On the one hand, the santana women want to increase their status to be self-defeating and liberating men to conquer. On the other hand, men from the middle class as describing their helplessness. In $B N$, the narrative delves into the image of a noble mind. The cacah and santana have to understand and accept that they live under the coordination of conquering with their feudal ideology that requires a multilevel society.

In $G N$, the narration scrambles were carried out in a complex manner. Desires seized the dominant discourses of the aristocrats' natives and the IndoDutch agreed through the use of the spirit of democracy. This democratic spirit used the subordinate actions of the colonial party represented by the IndoDutch. The santana's women conduct interrogations and intimidations against conquerors as subordinates to men who have power on the side of equality.

In an effort to reduce class issues, Salmun in the $G N$ inserts the whole class (cacah, santana, menak) into the pitfalls of mim pitu "the seven M" (maen "gambling", minum "drunk", madon "adultery", maling "stealing", mangani "spree", madat "using illegal drugs", and maehan "killing"). It is intended as a balancing narrative on the issue of contention and struggles over dominant narratives. Salmun finally puts the figures of the fearsome, Santana, and counters into the same fate. So, in $G N$ the struggle for dominant narratives between pribumi, pribumi over colonial, colonial over natives, is finally resolved through religious morals as a balancing narrative, whereas for $\mathrm{BN}$, the struggle for narration is limited to confirming that Santana's desire to become an illusion is merely an illusion.

Historically, concerning the exploration of power in the Dutch East Indies, Charles Jeurgens (2015: 122) mentioned that only at the lowest level in the Dutch East Indies government hierarchy did direct interaction between European and native actors. It means that lower administrative officials, such as district officials and resident assistants, play a decisive role in creating connections between the two worlds of information. In the $G N$, the colonial subjects represented through Indo-Dutch figures. The absence of administrative officials from the Dutch East Indies government in the two novels is not sufficient as the text is, but rather how the Indo-Dutch figures present problematically in the confusion of their identity. That characterizes colonial practices are always ambivalent. This condition is in line with the ambivalentconcept proposed by Homi Bhabha. Bhaha (in Loomba, 2003: 229) states that ambivalence is not only a marker of colonial subject trauma but also as a feature of the workings of the colonial authorities and their resistance. The colonial presence is always ambivalent, divided between showing its original and authoritative self and its articulation that shows repetition and difference. These conditions can impact on the natives who are in a dilemma between accepting and rejecting the influence present in their lives. 
In the $G N$, this ambivalent not only manifests in forms of contention and struggle over dominant narratives, but at the same time that compromises and sharespowernarratives with the colonial. At the very least, these compromises were made by indigenous priests to anticipate cultural and psychological distance from the colonial, and vice versa, colonials against the daughters. But in the end, the intermediaries took over. They took over similar to the natives and colonials.

\section{Gap and Blank Spaces}

As Iser understands, gaps \& blanks are spaces of text that activate the reader to produce the text he reads to the extent that the text can have an aesthetic impact. Iser (2006: 9) mentions three main concepts concerning the goals of modern theories, namely: (1) structure, (2) function, and (3) communication. These modern theories emphasize the relations between works of art, the disposition of readers, and (3) the reality of context. The action of communication, according to Iser's success (1987: 107), lies in the extent to which the text establishes itself as a correlate in the reader's consciousness. This means that the text provides guidance on what must be produced, and therefore the text itself cannot be a product. The success of text transfer to the reader depends on the success of the text to activate the perception and processing capacity of individual readers. This dynamic is shown by Iser (1987: 108) by mentioning the pleasure of the reader. According to him, the pleasure of the reader begins when the reader himself becomes productive, that is, if the text allows him to exert all his capacities. Of course, there are limits to the reader's willingness to participate.

The incompleteness of $B N$ and $G N$ disclosure are the potential that are connected to the problem of gaps and blanks text. Concerning the blanks form or gaps of the text can be explored from the unavailability of $G N$ which places some problems regarding social class, the views of the characters and the narrator, as well as things that are clearly shown by the author, or even things that are hidden.

So many narrative elements are made explicit in many events in $G N$. In $G N$ place, names are clearly shown with a description of the location mapping. The narrator is so detailed that Nyi Rapiah's family, Aom Usman, and Ujang Kusen's family are in the city of Bandung. This designation is mostly found through descriptions concerning Pasar Baru, Alun-alun Kabupaten, Jalan Pungkur, Jalan Kepatihan, Concordia, Braga, Cavadino shops, train lines along Bandung-Batawi, Banceuy, Preanger Hotel, Homan Hotel, Jalan Tamblong, Kebon Kalapa, Balubur, ect.

Regarding the completeness of the place in $G N$, readers who are already in the perspective of knowledge about Bandung, factually, will not only connect the interests of Salmun to choose the city as the setting, but will also discover the potentials within it concerning the insights of the figures in stories raised in the city's environment, social movements, lifestyle, or even the world of prostitution.

Concerning the name of the place explicitly, efforts to overcome textual gaps, which arise because of it, are more tangent to the problem of how the reader reconstructs his imagination 
concerning descriptions which limit the reader's reaction. The contact was centered on $G N$ narrative that connects the time of storytelling (1870$1880 \mathrm{~s})$ with the time of the creation of works (1950s). Salmun always puts the facts of the story concerning the places that he gave rise to in his present perspective. Thus, the reader, finally, accepts the effect of the condition of telling because he composes the facts based on the perspective they have, both inside and outside $G N$ storytelling areas. Readers who know the places referred to factually will react, in terms of imagining events in it, which is different from other readers, who in one condition lost the moment to look for references in events that are considered special and difficult to find references. For example, for the type of reader who loses the referral moment, the place of prostitution described in $G N$ with all its characteristics, text cracks in it can only be overcome by optimizing the reader's imagination.

The events connected to the practice of prostitution, in $G N$, are the central areas that Salmun deliberately chose. In this case, Salmun freely connected all the areas occupied by each social class group: menak-santana-cacah and of course the colonials. Prostitution area is an area that can be reached by all social class groups. Thus, for Salmun, this area is quite effective in placing figures from all of these groups into some judgments accompanying some behaviors in the world of prostitution.

Although the title of $G N$ refers to the explicit understanding that the temptation for young people is mim pitu but the center is the social class gap between menak and cacah.
The prostitution area was chosen by Salmun as mediation as well as an escape area and the rise of some of its figures. Through this area too, Salmun effectively discloses some ideal norms that are connected to each of their social classes.

The Nyi Dampi movement, from the lower class and as a procurer, has successfully entered all class boundaries. For her, a brothel can accommodate all class interests. It was not only the natives who made use of the place but also the Indo-Dutch. In this case, Salmun placed Nyi Rapiah as a figure who was able to accept and enter their lives while at the same time he was able to receive some new experiences, including the spirit of justice.

For the reader, some detailed descriptions, concerning all the life narrated by the narrator about prostitution, leave many gaps. The norms that are difficult to find are factual references regarding the hiding strategy of prostitution locations, causing the readers' imagination to reach out. Two different prostitution location conditions, marked by red lanterns and unmarked, lead the reader to two different perspectives, namely concealment, and appointment. The appointment of a brothel location with a red lantern, at least, enables the reader to connect the interests in it, not only to the security forces who want to free the community from life, but also the affirmation of the location which can instead be accessed directly by people with an interest in that location. This is more based on text restrictions that indicate that the sign is to prevent good people from entering the area. Regarding the hidden prostitution area, the reader 
is confronted with an understanding of the substance of the hidden location and the people involved in it.

Salmun chose to use a religious mask to hide the location of prostitution owned by Nyi Dampi. A paradox attached by Salmun means to provide a strong atmosphere for concealment in question. In this case, the reader must conclude from the paradox. At least what the reader can understand is that the paradox helps emphasize the importance of concealment. The things that are shown directly in $G N$, regarding the attitude of Nyi Rapiah towards the spooks, are also a paradox for concealing the involvement of people in the world of prostitution.

This will have implications for the broader structure of the reader's thinking. On the one hand, the reader understands that the world of prostitution in $G N$ provides an indirect, indirect reason for reaching out to the throne into such a world so that the throne is drawn into the "contemptible" area. On the other hand, in substance social class gaps are the soul of $G N$ story, the reader must look for on every surface that displays the life of prostitution. The hidden brothel owned by Nyi Dampi (commoners) can be connected to the actual substantial layer, namely $G N$ effort to include all social classes in the same meeting corridor. Their connection in the corridor will result in forms of contact between the affirmations gathered in $B N$ and $G N$ interrogation and intimidation to $B N$. In this case, the reader will calculate the continuity thematically in every event that contains the potential for the intended intersection so that other gaps re-emerge and re-connect to the reader's effort to overcome new gaps or even vacancies, for example concerning Indo-Dutch relations with the natives.

The narrative spaces stretched by Salmun from the beginning to the end of the story still stereotypically place the characters in it. This is evident from the non-emergence of prominent Dutch figures - not Indo-Dutch - and conquering aristocratic natives into the area. This does not mean that the reason for Salmun who intends to make disclosuresandevaluationscanbeagreed upon by the reader. For the reader, this absence is a blank text. The reader can finally find gaps in the text regarding the characters declared by the narrator as Indo-Dutch. This is not only tied to the events at the brothel or connected to it but also the confines of the stereotype concerning the authorities or even the dignity of a nation. The stereotype of native natives during the Dutch East Indies colonial era confirmed through the research of Nina Herlina (1998: 65) that describes the ideal of frightening ideas in the 19th century, not only can be seen in physical terms, it also from behavior. A ruler must be someone who has the charisma and the behavior of a nobleman; strong, capable, has a noble character, that is not acting up, not arrogant, affection for the poor, patient, wise, just, tolerant, he said, pure-hearted, and chivalrous. But in the $G N$, the aristocratic native are portrayed instead, in the $B N$, aristocratic native as well as showing their charisma and arbitrariness.

$G N$ has shown quite problematically the presence of Indo-Dutch figures in the native environment. Regarding this matter, Salmun has initiated his views, through the narrator, by placing Indo- 
Dutch figures as prominent figures in their relations with the natives. $\mathrm{He}$ placed some Dutch figures, who later made it clear to other parts, as IndoDutch people. Of course, throughout the moment of reading, in the end, it can to open the gaps of the text to be overcome by the reader. Finally, this can be seen in the events which gave rise to the narrator's views regarding the pleasure of the natives entering Dutch life.

Salmun pointed out the limitation of the relationship in question by placing natives figures closer to the Indo-Dutch; vice versa. He considered it to bring the natives to the ability to overcome the constraints of relationships that stem from social class differences. The change in Nyi Rapiah became confident with her attitudes shown by the narrator as a result of the Indo-Dutch people who were close to her. The gap shown in the following text stems from the Indo-Dutch status in some perceptions concerning relations and place among other social groups.

...Tjindekna mah Nji Rapiah teh dibobotohanweh. Meudjeuhnagedehate ge, da boga panjalindungan Walanda, paranakan-paranakan ge, mangkaning Walanda teh djaman harita mah, weu, lain lumajan diarambeuanana. (GN, 1966: 75).

Nyi Rapiah was indeed encouraged (by Luih). Naturally, if he was encouraged because he had the protection of a Netherlander even though only crossbreed; Moreover, at that time a Netherlander were so appreciated.

Through the narrator, the reader is directed to fill the text gap regarding the status of crossbreed. The text shows the quality of the relationship differently. The narrator said that it was enough for Nyi Rapiah to be encouraged because there were Dutch people who could be relied upon. However, the narrator later stated that the conditions possessed by Nyi Rapiah could be realized even though only through a crossbreed figure. The narrator still puts her fortune on Nyi Rapiah because he gets some life experiences from a Dutch crossbreed.

As a reality that readers can refer to in the interests of filling these gaps, Bezemer's opinion (in Gouda, 2007: 303) becomes relevant for placing crossbreed in certain perspectives. According to him, in the final years of Dutch colonial rule, a multi-colored mixed-blooded society in the Indies gained new meaning. Blind belief in the "whiteness" of universal European society, although some of its members are of mixed blood, lost some of its imaginative power. More clearly than in the past, the Indo described as mastering the space of shadows between white and brown, between employers and subordinates. They wander back and forth among the natives and the European community, and they are part of an unhappy, dissatisfied, and dangerous population.

The assessment, if used as information connected to the repertoire, will be reconstructed by the reader in the interest of gathering a broader reading perspective. The most relevant thing to the construction in question, to use the facts of reality in $G N$ reading concerning Hatebessy as Indo-Dutch, can be seen through the potential events faced by Hatebessy whose tanned skin when she would call herself white. This event will 
activate the reader into understanding body image and skin color. It will also stretch the range of reading to some events which again place the IndoDutch in a hierarchical relationship: Dutch, Indo-Dutch, natives. This is also the case with santana, in its closest hierarchical area: menak-santana-cacah.

The feeling of shame shown by Hatebessy intersects with the uncertain condition that befell santana circles over the thrill. The Indo-Dutch control of the natives or the restlessness of santana to seize control over the land and the relations between the two transition groups produced many othergaps. These gaps can be found and overcome by the reader as long as the reader is aware of the clashes of the text with some ideas concerning pangagung 'supreme ruler', both at the level of the local ruler or ruler of the Dutch East Indies. Pangagung, which is unreachable or intentionally hidden by the text for certain purposes, is another channel that the reader must look for and connect to a broader level. The readers can reach a broader scope by connecting the intersection of feudal perspectives with democracy, which leaves many readers with loopholes to overcome.

\section{The Conflicts and Identity Politics}

Identity politics works at the intersection of two cultures. In the context of colonialism, the contact was represented through discriminatory actions, curbing freedom, losing orientation, and lack of tolerance. The colonialism perspective of the Indonesian and world literary work demonstratedcomplexrelationsbetween East and West. In the comparison of East and West, the results of Yeni
Artanti's research (2020: 91) on the autobiography of Amélie Nothomb's StupeurEt Tremblements show differences in Western and Eastern cultures. According to him, these differences contributed to Amélie's ambiguity and assimilation process. This figure experienced discrimination and faced prejudice as a form of Eastern rejection of Westerners. Amélie represents the West, showing his experience of how his self-esteem lowered in the East. The self-criticism of Amélie Nothomb by laughing at herself through the novel is to create a balance in understanding the West and the East.

Through a review of green studies on the short story "Pohon Jejawi" by Budi Darma, Maimunah (2014: 336) concluded that the fight against colonialism was also carried out by tropical nature and the Indian earth ecosystem represented by the jejawi tree which was able to disrupt colonial peace and order. A similar disturbance in the order shown by Sudibyo regarding the uncanny phenomenon in the postcolonial novel of the Dutch East Indies. Sudibyo (2017: 225-226) said that uncanny phenomenon as a loss of Indo-Dutch orientation to a foreign and threatening place of residence. Indo-Dutch and natives figures also felt to be an inseparable part of the Indies. The Indies were their only homeland so that when these valuable assets were forcibly taken away by various political situations that occurred in Indonesia, they lost their orientation.

The intersection of two cultures with the effects it produces in GN is complex. Butin $B N$, the conflict was builtinternally native. The intersection of two cultures with the effects it produces in $G N$ is also 
complex but conflict contained in $G N$ was dominantly occupied by santana represented by a female figure named Nyi Rapiah. The internal dispute between cacah-santana and menak of $G N$ focuses more on verbal attacks (interrogation \& intimidation) and acts of weakening and entrapment by Nyi Rapiah to lead menak into humiliation. Menak were weakened by the way the prominent spirit of democracy brought by Nyi Rapiah from her association with the Indo-Dutch; menak are humiliated by using the trap of prostitution. Feudalism which is opposed by Nyi Rapiah due to the emergence of class disparities has been fought against in a spirit of democracy. The courage of the main character to carry out his attack to menak initially originated in the selfunderstanding of the characters as the lower classes who were considered not to care about politeness in speaking, behaving, and acting. Therefore, she has the power to fight menak directly with her capital. The emphasis of menak arrogance is done in a way, one of which, through the appointment of wealth. On the other hand, selfunderstanding of wildness which is not normatively limited leads santana into the corridor of association with the Indo-Dutch. On his golden opportunity, he absorbed democratic enthusiasm which was finally able to raise himself against feudalism and at the same time seize his authoritative signs, both from the conquerors and the colonials.

Another major sign of alignments with the lower classes is shown by increasing the potential of figures representing santana class. The improvement is intended to restore the situation of figures who should get a good place and appreciation from their environment. It appears that male figures who were thrown into prison due to the arbitrariness of the people of menak, in $G N$ were restored through the ability to write characters who on average at that time the community was not literate. Gradually, the character becomes a respected figure in the detention environment. In the end, $G N$ wanted an arbitrary person to endure similar misery. He went to prison to replace the figure of santana who had been released. On another perspective, Nyi Rapiah weakened colonial domination and arrogance by utilizing her body and consciousness in fighting for her freedom. She not only deceived the people in the trap of prostitution but also the colonials. She was aware that her society had long been subordinated by the colonials.

Regarding the scramble narratives, the author of GN composed the narration mostly occupied by santana who struggled to demand equality. Menak and the colonials (represented by Indo-Dutch) were only placed as objects of interrogation and intimidation by santana. The rest of the three groups (santana-cacah, menak, and colonials) narrated away at risk of humiliation, including Nyi Rapiah who fought for equality and liberation in the confines of the conquerors and the colonials.

In the context of the scramble narratives and as a reader respons, if related to $B N, G N$ changes its perspective. The authorities carried out by menak in $B N$ were taken over by $G N$ by reversing it: santana who came to power. Changing that perspective as an effort to fight over narration while promoting the movement of democracy 
which is considered by the author to be welcomed and carried out to reorganize life and overcome class problems. The narrative processing in $G N$ does not stop with the spirit of democracy, but also how mim pitu is used as the main warning (maen "gambling", minum "drunk", madon "adultery", maling "stealing", mangani "spree", madat "using illegal drugs", and maehan "killing"). Through mim pitu, GN has summarized all the problems in it and stopped at events to bear the bitter fate events consecuence of mim pitu.

In line with the potential of the narrative regarding class struggle, $G N$ finally leaves space for reading regarding identity politics. Textually, $G N$ that places class battles in it will ultimately show how its identity and opposition become the main discourse. The appointment of contradictions in it represents identity politics built in the name of democracy. Because what is dominant in $G N$ is the authoritative effort of santana over menak and the colonials, the politics of identity that is nested within it also places santana as the main sign that builds awareness of its identity as the lower classes who must fight for equal rights and even eliminate class differences. The main sign is shown through the awareness of the value of the holdings of santana which are not bound to the strict norms that bind them so that these conditions have the opportunity to lead santana to the courage to demand their rights as well as the willingness to mingle and learn to understand democracy which is channeled through the knowledge possessed by youth- Indo-Dutch youth. The middle and lower classes (santana \& cacah) have been demeaned by menak and the colonials. They consider the middle and lower classes have no ethics and live without regard to norms. Based on this assessment, the middle classes represented by Nyi Rapiah class increasingly have the power to directly show their protests over the abuse of the upper class. It is in this spirit of struggle that identity politics is built through the critical attitudes of the lower classes towards the upper classes: on the one hand, the use of awareness of selfproclaiming as the lower classes can act anything abnormally to achieve the desire for equality; on the other hand, this awareness becomes the power to truly take over the domination and authoritative attitudes of menak and colonials.

In an extra-textual perspective, $G N$ has positioned itself as a work that rejects "class" ideologies of $B N$. Through his sympathetic strategy towards the lower classes depicted in $G N$ although in the end the sympathetic feeling was reduced to the pitfalls of mim pitu, Salmun had established his identity politics as part of citizens who were aware of their duty to carry out the spirit of democracy which fought in the spirit of democracy. As for the placement of the work culture that distinguishes masterpiece works from kitsch's, based on $G N$ he has written, Salmun has placed himself as a person that does not bind himself to the fulfillment of the requirements of masterpiece work. He was so free and straight forward to express the realities of his day which were elevated into $G N$ in his way. This condition is commensurate with what he has shown through $G N$ narratives in which he is more sympathetic to the lower classes and rejects the establishment of the 
norms of menak so that the democracy spirit that he wishes to highlight in $G N$ can be effectively achieved.

\section{CONCLUSION}

The natives who narrate themselves in the struggle for class authority are a space for the appointment of identity politics. The appointment of local and modern values in the interests of the struggle for rights in their social environment becomes an empowering tool in the political interests of the identity they build. The middle class (santana) expresses the importance of freeing themselves from their oppression and the rights which are taken away by the authorities. The method of his release was carried out through the efforts to weaken the authority of menak and the colonials. The concern over their class disparity is shown through openly replying (intimidation and interrogation) towards them. This method of intimidation and interrogation is the main sign used by the author to build a new perspective on the struggle of the middle and lower classes in achieving equality of rights. Salmun reduced the class problem to the moral side. He asserted that the glory and humiliation belonged to anyone. On the textual side, the weakening of feudalism through the spirit of democracy is the politics of identity shown by santana over the authority of menak and the colonials. Through this politics, the spirit of feudalism was deliberately changed towards a popular spirit to emphasize the struggle of the lower classes in achieving equality and liberation. On the extra-textual side, the point of offering awareness values about the popular spirit contained in $G N$ has demonstrated the identity politics established by Salmun to reject the feudal ideology contained in $B N$ and at the same time, Salmun accepted the democracy spirit introduced by the colonials to the natives in the late 19th century.

In $G N$, the reader is stimulated to take a negative attitude towards what is stated in $B N$ concerning the social class. Through GN, Salmun also offers a democratic spirit incessantly. Such conditions certainly give birth to overdetermination which will pave the way for the creation of gaps $\&$ blanks again. Some gaps and blanks regarding identity problems (ethnicity, Indonesian-native relations, city-village, etc.) contained in $G N$ as readers respons to $B N$ certainly need to be filled through the mental map of the reader who empowers his knowledge, both regarding knowledge of $B N, G N$, and relations $G N$ against $B N$. The freedom to fill the empty spaces of the text in the effort of meaning is only born from the construction developed from the pattern offered by the text. Thus, it can be seen that some blanks spaces in $G N$ are dialectically shown by the two works concerning: (1) the world of prostitution in $G N$ is a functional space to facilitate interrogation and intimidation against $B N$ and (2) IndoDutch and native relations as an accentuation of democracy in the power of santana towards menak. Of course, the blank spaces and the construction of readings in filling the blanks in question are not a permanent and absolute part. Thus, each reading activity at different moments by the same or different readers will certainly give birth to different reading opportunities. In such conditions, blank spaces are likely to be 
found again, also the reading of identity politics.

\section{ACKNOWLEDGEMENT}

This article is an output from research funded by Hibah Internal Unpad. We should like to thank those who have contributed to this research, especially Rector of Padjadjaran University, Director of DRPM Unpad, Dean of the Faculty of Cultural Sciences Unpad, and Chair of the Sunda Cultural Study Center in Faculty of Cultural Sciences Unpad. We should also like to thank reviewers who have read and provided input on the improvement of this article.

\section{REFERENCES}

Ardiwinata, D.K. (1950). Baruang ka nu Ngarora. $3^{\text {rd }}$ printing. Jakarta: Balai Pustaka

Artanti, Y. (2020). "Kosep Diri Perempuan di Persimpangan Budaya dalam Autobiografi Stupeur Et Tremblements Karya Amélie". LITERA, Volume 19, Nomor 1, Maret 2020. https://doi.org/10.21831/ltr. v19i1.30465

Barker, C. (2005). Cultural Studies: Teori dan Praktik. Yogyakarta: Bentang

Baumeister, A. (2009). Gender, Culture and The Politics of Identity in The Public Realm, Journal of Critical Review of International Social and Political Philosophy, 12:2, 259-277, http://doi. org/10.1080/13698230902892176

Couze Venn (2010). Aesthetics, Politics, Identity: Diasporic Problematisations. Journal of Critical Arts: South-North Cultural and Media Studies. 24:3, 321 347, https://doi.o $\mathrm{rg} / 10.1080 / 02560046.2010 .511870$
Herlina, N. (1998). Kehidupan Kaum Menak Priangan 1800-1942. Bandung: Pusat Informasi Kebudayaan Sunda.

Hutcheon, L. (2004). Politik Posmodernisme. Yogyakarta: Jendela.

Hudayat, A. Y. (2012). Novel Sunda dalam Jaring Estetika Suara-suara Kelas. Bandung: Syabas Books.

Iser, W. (1987). The Act of Reading: $A$ Theory of Aesthetic Respone. $4^{\text {th }}$ printing. Baltimore \& London: The John Hopkins University Press.

Iser, W. (2006). How to Do Theory. USAUK-Australia: Black Well.

Jeurgens, C. (2015). "Network of Information: The Dutch Indie" in Exploring The Dutch Empire. Antunes, Catia \& Gommans, Jos (ed.). London-New Delhi-New York-Sydney: Bloomsbury

Loomba, A. (2003). Kolonialisme/ pascakolonialisme. diterjemahkan Hartono Hadi. Yogyakarta: Narasi

Maimunah. (2014). Perlawanan Alam terhadap Kolonialisme dalam Novel Pohon Jejawi Karya Budi Darma. LITERA, Volume 13, Nomor 2, Oktober 2014 https://doi.org/10.21831/1tr. v13i2.2585

Salmun, (1966). Gogoda ka nu Ngarora. Bandung-Jakarta: Pusaka SundaBalai Pustaka

Sudibyo. (2017).Uncanny dan BayangBayang Koloni dalam Novel Poskolonial Hindia Belanda. LITERA, Volume 16, Nomor 2, Oktober 2017 https://doi.org/10.21831/ltr. v16i2.15587

Van der Meer, Arnout Henricus Cornelis. (2014). Ambivalent Hegemony: Culture and Power in 
Colonial Java, 1808-1927. Disertasi. New Brunswick, New Jersey: The Graduate School-New Brunswick Rutgers, The State University of New Jersey
Younge, G. (2019). The Politics of Identity: From Potential to Pitfalls, and Symbols to Substance, Identities, Journal of Identities Global Studies in Culture and Power ,26:1, 1-11, https://doi.org/10.1080/107 0289X.2018.1508859 